\title{
Herbicide injuries on blueberry provide suitable infection sites for Neofusicoccum ribis
}

\author{
K.M.S. Tennakoon, M.V. Jaspers, H.J. Ridgway and E.E. Jones \\ Faculty of Agriculture and Life Sciences, Box 85084, Lincoln University, New Zealand \\ Corresponding author: Kulatunga.Tennakoon@lincolnuni.ac.nz
}

\begin{abstract}
Botryosphaeria dieback of blueberry is caused by several botryosphariaceous species including Neofusicoccum ribis. This research investigated whether stem damage caused by three herbicides could allow for penetration of blueberry stems by this pathogen. Results showed that all the herbicides damaged hard green shoots, of which 100\% were penetrated by the inoculated $N$. ribis. Mean lesion lengths were similar for all herbicides and the inoculated wounded control $(\mathrm{P}=0.240)$. Isolations from bark and wood showed similar infected proportions for bark $(\mathrm{P}=0.14)$ but different proportions for wood $(\mathrm{P}=0.035)$. These mean proportions were: $76.4 \%$ for bark and $82.5 \%$ for wood when treated with glufosinate-ammonium, $74.6 \%$ and $75.0 \%$ with paraquat+diquat, $66.9 \%$ and $61.4 \%$ with carfentrazone-ethyl, and $58.1 \%$ and $60.4 \%$ for the inoculated wounded control. This study has indicated that herbicide damage can create entry ports for stem pathogens, and highlights the importance of careful herbicide application to manage understorey weeds in blueberry farms.
\end{abstract}

Keywords dieback, blueberries, stem damage.

\section{INTRODUCTION}

Botryosphariaceous species have been associated with canker and dieback symptoms in a broad range of different perennial fruit crops worldwide, and their importance as canker-causing and fruit rot agents is well recognised (Espinoza et al. 2009). In New Zealand, dieback and crown rot in blueberry orchards are emerging problems, and were estimated to affect approximately $18 \%$ of blueberry plants in the main production areas, costing approximately $\$ 500,000$ annually due to yield losses and replanting costs (Sammonds et al. 2009). Recent research has shown that the most common botryosphariaceous species to infect blueberry in New Zealand were Neofusicoccum parvum, $N$. luteum, $N$. australe and $N$. ribis. All species caused $100 \%$ infection incidence in inoculated plants, but $N$. ribis was the most pathogenic, causing rapid wilting and reddening of leaves on affected branches, systemic branch dieback, trunk cankers and death of plants (K.M.S. Tennakoon, unpublished data). The wounds, which were typically required for infection by these pathogens, may be caused by mechanical harvesters, pruning, winter freezing damage or chemical damage. Anecdotal reports of gramoxone injury on young stem bases predisposing them to stem blight infections led Cline (1997) to suggest that herbicide-damaged areas were potential infection courts. Subtoxic levels of herbicides have been reported to increase or decrease resistance to plant diseases via indirect effects on plants (Duke et al. 2007). 
This study was undertaken to investigate whether the herbicides commonly used to control understorey weeds in New Zealand blueberry farms (G.I. Langford, Berryworld Ltd, personal communication) could cause damage sites suitable for infection by $N$. ribis.

\section{MATERIALS AND METHODS}

Blueberry plants, variety 'Centurion blue' (10 years old), established in the field at Lincoln University were used for this experiment, which was conducted in November 2014. Three widely used herbicides, glufosinate-ammonium, paraquat+diquat and carfentrazone-ethyl, were applied at the recommended field rates (Table 1). The 1-year-old hard green shoots on the outer sides of the bushes that arose from the trunks were selected. The unbranched lower sections were carefully sprayed with a hand-sprayer for a length of $50 \mathrm{~cm}$, beginning $10 \mathrm{~cm}$ from the trunk until covered with fine droplets. The treated areas were observed for signs of discolouration after $1,2,3,4,6,7$ and 10 days. The areas for inoculation (ca $1 \mathrm{~cm}^{2}$ ) were then marked centrally within the discoloured sections and inoculated with $50 \mu \mathrm{l}$ of a mixed isolate conidial suspension $\left(10^{5}\right.$ conidia $\left./ \mathrm{ml}\right)$ of Neofusicoccum ribis (isolates S1-175 and S1- 158). Parafilm ${ }^{\circledR}$ was wrapped around each stem at this site in such a way as to create a cup, which helped to prevent the $2 \mathrm{~mm}$ droplet of inoculum from running off. Each inoculated shoot was covered with a new polythene bag, misted inside with water to provide high humidity and left in place for $48 \mathrm{~h}$. Two shoots were treated on each plant, with six replicate plants for each treatment, including the wounded $(6-8 \mathrm{~mm}$ of $1-2 \mathrm{~mm}$ depth), inoculated, water-treated control plants. There were also two plants treated with the herbicides but not inoculated, which provided a check that any developing lesions were due to the pathogen and that the plants were initially free of this pathogen. Plants were selected for each treatment according to a completely randomised design. Two shoots on one extra plant for each herbicide were set up to allow for exploratory dissections that would indicate the most appropriate time for assessments.

Plants were assessed 30 days after inoculation. The central $20 \mathrm{~cm}$ sections of the shoots (from $10 \mathrm{~cm}$ below to $10 \mathrm{~cm}$ above the inoculation points) were harvested. They were surface sterilised by soaking in $70 \%$ ethanol for $30 \mathrm{~s}$ and air dried in a laminar flow cabinet for $10 \mathrm{~min}$. The bark was then removed from each section in a single sheet to expose the light brown lesions, which were measured using a digital calliper (Mitutoyo, U.K.). Tissue pieces were cut at $1 \mathrm{~cm}$ intervals for isolation. Bark and wood tissues were plated separately onto potato dextrose agar (PDA; Difco), with tissue placement on the agar plates indicating their positions on individual shoots. The plates were incubated at $25^{\circ} \mathrm{C}$ in $12: 12 \mathrm{~h}$ light:dark for 5 days, and the isolates identified by colony appearance. Data were analysed by ANOVA using Genstat version 16. Treatment means were compared by Fisher's protected LSD tests at $\mathrm{P}<0.05$.

\section{RESULTS}

The shoot areas that were sprayed with each herbicide developed dark brown to black discolouration within 10 days. Mean lesion lengths (Table 2) were similar for the inoculated, herbicide-treated shoots and the wounded, inoculated controls. Pale brown discolouration was visible under the bark within 14-30 days after inoculation, but was not evident in the non-inoculated herbicide controls even after

Table 1 Herbicides used to create injury to blueberry plants prior to inoculation with Neofusicoccum ribis conidia.

\begin{tabular}{llllc}
\hline Active ingredient & Trade name & Chemical class & Manufacturer & $\begin{array}{c}\text { Use rate } \\
\text { (ml/100 litres) }\end{array}$ \\
\hline Glufosinate-ammonium & Buster $^{\circledR}$ & $\begin{array}{l}\text { Ammonium } \\
\text { phosphate }\end{array}$ & Bayer Crop Science & 750 \\
Carfentrazone-ethyl & Shark $^{\circledR}$ & $\begin{array}{l}\text { Triazoline } \\
\text { Paraquat+ diquat }\end{array}$ & FMC & 300 \\
\hline
\end{tabular}


30 days. There was $100 \%$ incidence of lesions in inoculated shoots, whether wounded or treated with either of the herbicides, but $0 \%$ incidence in the non-inoculated shoots. Isolations made from bark and wood showed continuous colonisation from the inoculation point but only for part of each section. There was no herbicide effect on the proportion of infected bark $(\mathrm{P}=0.14)$ but a significant effect for wood ( $\mathrm{P}=0.035)$ (Table 2$)$. The mean proportion of infected wood pieces from the $20 \mathrm{~cm}$ length of shoot was greatest $(\mathrm{P}<0.05)$ for shoots treated with glufosinateammonium $(82.5 \%)$ and least $(\mathrm{P}<0.05)$ for those treated with carfentrazone-ethyl $(61.4 \%)$ and the inoculated control (60.4\%).

\section{DISCUSSION}

This is the first study in New Zealand to investigate whether herbicide injuries in blueberry plants can affect infection by botryosphariaceous species. In inoculated and non-inoculated plants, the herbicides caused bark on stems to become dark brown to black, clearly indicating dead bark tissues. Dark brown discolouration on the bark of blueberry plants damaged by spraying fluroxypyr and glyphosate for weeds control have been reported in a blueberry orchard in the Hawke's Bay region (M. Hirst, personal communication). The plants showed dieback symptoms while plants in a non-treated block were healthy.

Results of the present study also showed that herbicide-damaged bark had allowed $N$. ribis to penetrate the underlying wood, with the same degree of infection previously seen in the inoculated mechanical wounds (K.M.S. Tennakoon, unpublished data). A similar effect was reported from a Mississippi, USA, farm during the late 1980s (Smith 1997); the greater incidence of stem blight in blueberry coincided with injury to the base of young canes caused by contact herbicides such as paraquat. However, Smith (1997) also reported that incidence of stem blight had declined as growers learnt to avoid injuring blueberry canes with paraquat. In the current study, the lesion lengths of herbicide-treated and inoculated controls were similar. However, results indicated a trend for larger lesions when the bark was mechanically damaged in the control plants than in the herbicide-damaged plants. This may have been due to the toxic effects of the herbicides which slowed development of the inoculated fungus. A similar observation was made by Cohen et al. (1996), who reported decreased vascular wilt in melon caused by Fusarium oxysporum after acetochlor treatment.

In the present study, there was $100 \%$ disease incidence in all herbicide treated shoots. In contrast Cline (1997) isolated a botryosphaeriaceous pathogen Fusicoccum aesculi from $50 \%$ of injured blueberry stems in a field of the 2-3 year old 'Premier' blueberry plants, which showed $25-95 \%$ plant death due to herbicide injury from improperly used paraquat dichloride. However, New Zealand studies have found lower incidence of botryosphaeriaceous pathogens in dead tissues than in living, declining

Table 2 Mean lengths of external lesions ( $\mathrm{mm}$ ) and mean infected proportions (\%) of bark or wood from $20 \mathrm{~cm}$ shoots in 1-year-old hard green blueberry shoots treated with different herbicides, at 30 days after inoculation with Neofusococcum ribis conidia.

\begin{tabular}{lccl}
\hline Herbicide & Lesion lengths & Infected bark (\%) & Infected wood (\%) \\
\hline Glufosinate-ammonium & 11.7 & 76.4 & $82.5 \mathrm{~b}^{1}$ \\
Paraquat+ diquat & 8.8 & 66.9 & $61.4 \mathrm{a}$ \\
Carfentrazone-ethyl & 7.3 & 74.6 & $75.0 \mathrm{ab}$ \\
Control (inoculated only) & 16.5 & 58.1 & $60.4 \mathrm{a}$ \\
\hline
\end{tabular}

${ }^{1}$ Means within columns followed by the same letters are not significantly different according to Fisher's Protected LSD at $\mathrm{P}<0.05$. Herbicide effect on infected proportion in the wood was significant $(\mathrm{P}=0.035$; $\mathrm{LSD}=16.98)$. 
tissues (M.V. Jaspers, personal communication), and low inoculum levels may have caused the lower than expected incidence in the study by Cline (1997).

The herbicides tested had different effects on the infected proportions of wood in inoculated plants. Overall, this was greatest in plants treated with glufosinate-ammonium, which has a systemic effect, whereas the other herbicides have contact activity. The likely toxic effects of this herbicide has been reported to be associated with nitrogen metabolism within plants. Mersey et al. (1990) reported that glufosinate-ammonium irreversibly inhibited glutamine synthetase in plants, resulting in rapid accumulation of potentially toxic ammonia within plant cells. Since most fungi can metabolise ammonium compounds (Deacon 2006), this may directly increase host susceptibility to diseases including those caused by botryosphaeriaceous species.

This study has identified a risk factor for development of Botryosphaeria dieback in blueberry and highlighted the importance of targeted application of herbicides for control of understorey weeds. The use of shielded sprayers for application of herbicides or avoidance of herbicide use may reduce damage by Botryosphaeria dieback in blueberry farms.

\section{ACKNOWLEDGEMENTS}

The authors wish to thank Geoff Langford for his advice.

\section{REFERENCES}

Cline WO 1997 Predicting blueberry stem blight in new plantings. Acta Horticulturae 446: 421-426.

Cohen R, Blaier B, Schaffer AA, Katan J 1996. Effect of acetochlor treatment on Fusarium wilt and sugar content in melon seedlings. European Journal of Plant Pathology 102: 45-50

Deacon J 2006. Fungal Biology. Blackwell Publishing, UK. 118 pp.

Duke SO, Wedge DE, Cerdeira AL, Matallo MB 2007. Herbicide effects on plant disease. Outlooks Pest Management 18: 36-40.

Espinoza JG, Braceno EX, Chavez ER, UrbezTorres JR, Latorre BA 2009. Neofusicoccum spp. associated with stem canker and dieback of blueberry in Chile. Plant Disease 93 (11): 1187-1194.

Mersey BG, Hall JC, Anderson DM, Swanton CJ 1990. Factors affecting the herbicidal activity of glufosinate-ammonium: absorption, translocation, and metabolism in barley and green foxtail. Pesticide Biochemistry and Physiology 37(1): 90-98.

Sammonds J, Billones R., Rocchetti M, Ridgway HJ, Walter M, Jaspers MV 2009. Survey of blueberry farms for Botryosphaeria dieback and crown rot pathogens. New Zealand Plant Protection 62: 238-242.

Smith BJ 1997. Detached stem assay to evaluate the severity of stem blight of rabbiteye blueberry (Vaccinium ashei). Acta Horticulturae 446: 457-464. 